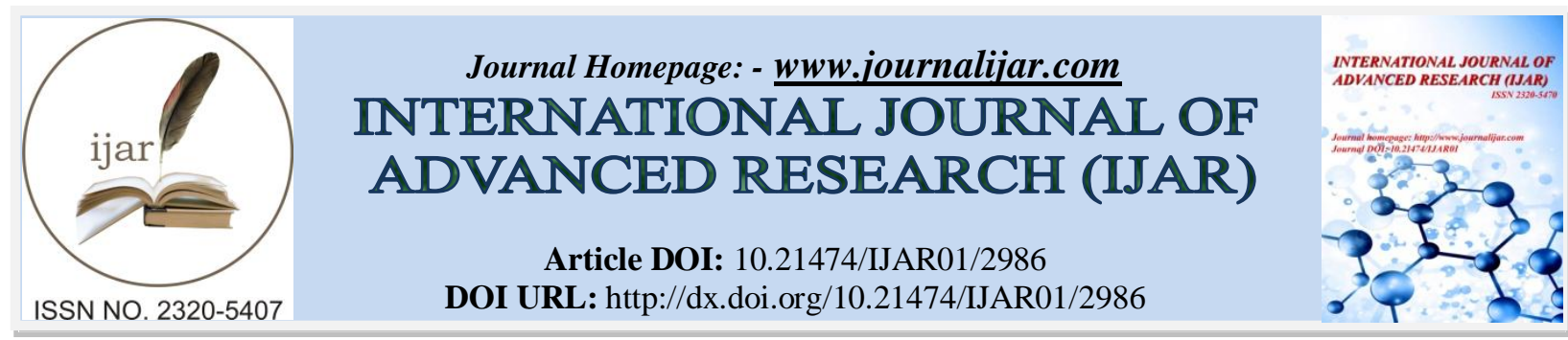

RESEARCH ARTICLE

\title{
IMPACT OF EMOTIONAL INTELLIGENCE ON THE ACADEMIC ACHIEVEMENT OF D.EI.ED STUDENTS.
}

1. Ph.D. Scholar cum Lecturer, DIET, Munanjipatti, Tirunelveli.

2. Assistant Professor, Department of Education (DD\&CE), Manonmaniam Sundaranar University, Tirunelvlei.

\section{Manuscript Info}

Manuscript History

Received: 28 November 2016

Final Accepted: 27 December 2016

Published: January 2017

\begin{abstract}
The present study is conducted among the 739 students of teacher trainees for analyzing the impact of Non cognitive factor on the academic achievement. Self made tool is adopted for testing an emotional intelligence of the teacher trainees. And also the researcher has developed academic achievement tool in 2015 with the help of the Source book, tested at the $0.05 \& 0.01$ percent level of significance. The participants are considered male and female students in, which strength of female more than male students. The result of study reveals that there is positive and significant difference between Emotional Intelligence and Academic Achievement of teacher trainees.
\end{abstract}

Copy Right, IJAR, 2016,. All rights reserved.

\section{Introduction:-}

Human life is full of events everyday and every event of a man's personal life is expressed in some emotional colouring. Behind every emotion there is a feeling. Feelings are described as emotions. Our emotions play quite a significant role in guiding and directing our behaviour. Many a time there are seen to dominate our behaviour in such a way that we have no solution other than behaving a per wish. On the other hand, if a person has no emotional current he them he becomes crippled in terms of living his life in a normal way. Hence, emotions play a key role in providing a particular direction to our behaviour and thus shaping our personality according to their development.

Emotional intelligence consists of two words Emotion and Intelligence. Emotion refers to intense feeling of human. Intelligence is basically based on mental ability of human to deal effectively with the environment. Emotional intelligence is the ability to sense and understand one's own emotions, to express and regulate then appropriately and to use them in the process of decision making. It includes the capacity to understand and feel for others, and so set up maintain quality relationships.

From Salovey and Mayer's theoretical model, EI is conceived as an authentic intelligence, based on the adaptive use of emotions such that the individual can solve problems effectively adjust to his or her surroundings. Mayer and Salovey's skill model considers that EI conceptualized through four basic skills. "the skill of accurate perception, appraisal and expression of emotions, the skill of taking on and/or generating feelings which facilitate thinking; the skill of understanding emotions and emotional knowledge and the skill or regulating emotions, thus promoting emotional and intellectual growth" (Mayer \& Salovey, 1997).

Corresponding Author:- J. Ramani.

Address:- Ph.D. Scholar cum Lecturer, DIET, Munanjipatti, Tirunelveli. 


\section{Emotional Intelligence and Academic Performance:-}

The ability to pay attention to their emotions, experience feelings with clarity and be able to recover from negative states of mind will be a decisive influence on students' mental health, and this psychological balance in turn is related to and ultimately affects academic performance. Persons with limited emotional skills are more likely to experience stress and emotional difficulties during their studies, and consequently will benefit more from the use of adaptive emotional skills that allow them to cope with these difficulties. EI may act as a moderator of the effects of cognitive skills on academic performance (Brackett, 2011)

\section{Need and significance of the study:-}

The result of present study will provide a base which may help in strengthening or improving the achievement of the adolescents. The findings will also act as a linkage of emotional intelligence and creative thinking ability which in turn imparts a significant role in the development and achievements of adolescents. In the words of Smith (2009) in Teachers for the Real Word keeping in mind the present day requirements remarks, If a student's is to be prepared for the evolving world, than an essential attribute of effective teacher is awareness of the realities of the world. Therefore, the primary school teachers have a great role in moulding future generation. In order to be better teachers, they need to be emotionally intelligent, creative and effective in their performance. The foundational seed to reach to this state is being sown in the initial stages of schooling. The potential seed is sown by the primary school teachers. Therefore, the investigator inclines to study the variables emotional Intelligence, creative thinking ability and academic achievement of D.EI.Ed students.

Title of the study:-

Statement of the problem is entitled as Impact of emotional Intelligence on the Academic Achievement of D.EI.Ed Students.

\section{Objectives of the study:-}

The following objectives have been formulated for the purpose of the study:

1. To find out the level of emotional intelligence of D.EI.Ed students.

2. To find out the level of Academic achievement of D.EI.Ed students.

3. To find out the difference, if any, in the Emotional intelligence of D.EI.Ed students in terms of demographic variables such as gender, nature of institution and marital status.

4. To find out the difference, if any, in the Academic Achievement of D.EI.Ed students in terms of demographic variables such as gender, nature of institution and marital status.

\section{Methodology:-}

The investigator adopted survey method. This method of investigation which attempts to describe and interpret what exists at present in the form of conditions practices, process, trends, effects, beliefs etc. The survey method gathers data from relatively large number of case at a particular time.

\section{Sample:-}

The investigator had used stratified random sampling technique for selecting the sample. The investigator randomly selected the Teacher trainees from three districts are Tirunelveli, Tuticorin and kanyakumari. The selection was done on the basic of the type of institution and location of the institution. From these institutions, 739 teacher trainees were randomly selected on the basis of the criteria.

\section{Research Tools:-}

Emotional Intelligence tool designed by Rasel. Academic Achievement tool developed by the researcher in the year 2015, with the help of source book.

\section{Procedures:-}

The above inventory was administered to subjects. Each item was scored with the help of scoring key. The data thus collected are tabulated to arrive at meaningful inference.

\section{Statistical Techniques:-}

The tabulation and analysis of data done by using appropriate statistical techniques such as Mean, Standard deviation and ' $\mathrm{t}$ ' test. 


\section{Data Analysis:-}

To find out the meaningful interpretation of the raw scores the data were analyzed, the results of the study are presented in the following tables.

Table - 1 Level of emotional intelligence and academic achievement of d.ei.ed students

\begin{tabular}{|l|c|c|c|c|c|c|}
\hline \multirow{2}{*}{ Category } & \multicolumn{2}{|c|}{ Low } & \multicolumn{2}{c|}{ Moderate } & \multicolumn{2}{c|}{ High } \\
\cline { 2 - 7 } & No. & \% & No & \% & No & \% \\
\hline Emotional Intelligence & 100 & 13.5 & 547 & 74.0 & 922 & 12.4 \\
\hline Academic Achievement & 146 & 19.8 & 485 & 65.6 & 108 & 14.6 \\
\hline
\end{tabular}

The table indicates that 13.5 of the D.EI.Ed students have low level, 74.0 percent have average level and 12.4 percent have high level of emotional intelligence. It is inferred from the table reveals that 19.8 percent of the D.EI.Ed students have low level, 65.6 percent have moderate level and 14.6 percent have high level of academic achievement. Further it is concluded that a good percentage of D.EI.Ed students have average level of emotional intelligence and academic achievement.

Table - 2 significant difference among the emotional intelligence of d.ei.ed students in terms of demographic variables

\begin{tabular}{|c|l|c|c|c|c|c|c|}
\hline \multicolumn{2}{|c|}{ Emotional Intelligence } & $\mathbf{N}$ & Mean & SD & DF & Calculated 't' value & $\rho$-value \\
\hline \multirow{2}{*}{ Gender } & Male & 40 & 230.18 & 24.810 & 737 & 0.234 & $0.815 \mathrm{NS}$ \\
\cline { 2 - 6 } & Female & 699 & 229.32 & 22.326 & & & \\
\hline \multirow{2}{*}{$\begin{array}{c}\text { Nature of } \\
\text { Institution }\end{array}$} & Girls & 329 & 226.21 & 23.616 & 737 & 3.450 & $0.001^{* *}$ \\
\cline { 2 - 5 } Marital Status & Co-Education & 410 & 231.90 & 21.160 & & & \\
\cline { 2 - 8 } & Married & 86 & 233.56 & 17.811 & 737 & 2.237 & $0.027^{*}$ \\
\cline { 2 - 5 } & Unmarried & 653 & 228.81 & 22.946 & & & \\
\hline
\end{tabular}

$\mathrm{S}^{* *}=$ Significant at $1 \%$ level. $\mathrm{S}^{*}=$ Significant at $5 \%$ level NS = Not significant

The calculated $\rho$ value for the variable of Emotional intelligence as a more than 0.05 level of significance and so are not significant at 5\% level. It means that there is no significant difference in the Emotional intelligence of D.EI.Ed student due to their gender. Hence the formulated null hypothesis, 'there is no significant difference in the emotional intelligence of D.EI.Ed students due to their gender to which they belong" is accepted.

The calculated $\rho$ value for the variable of Emotional intelligence as less them 0.01 and so they are significant at 1 percent level. It means that there is significant difference in the nature of institution of D.EI.Ed students. While comparing the mean scores, girls institute $($ mean $=226.21)$ and co-education institute (mean $=231.90)$. Further it is observed that the co-education institute D.EI.Ed students are better than their girls institute counter parts in Emotional intelligence.

The calculated $\rho$ value for the variable of Emotional intelligence as less than 0.05 and so they are significant at 5 percent level. It means that there is significant difference in the marital status of D.EI.Ed students. While comparing the mean scores of married $(m e n=233.56)$ and unmarried D.EI.Ed students (means $=228.81)$. Further it is observed that the married D.EI.Ed students are better than their unmarried D.EI.Ed students in their Emotional intelligence.

Table - 3 Significant difference among the emotional intelligence on the academic achievement of d.ei.ed students in terms of demographic variables

\begin{tabular}{|c|l|c|c|c|c|c|c|}
\hline \multicolumn{2}{|c|}{ Academic Achievement } & N & Mean & SD & DF & $\begin{array}{c}\text { Calculated } \\
\text { 't' value }\end{array}$ & $\rho$-value \\
\hline \multirow{2}{*}{ Gender } & Male & 40 & 32.5 & 9.541 & 737 & 1.975 & $0.049^{*}$ \\
\cline { 2 - 7 } & Female & 699 & 34.92 & 8.890 & & & \\
\hline \multirow{2}{*}{$\begin{array}{c}\text { Nature of } \\
\text { Institution }\end{array}$} & Girls & 329 & 36.64 & 9.085 & 737 & 5.220 & $0.000^{* *}$ \\
\cline { 2 - 5 } Marital Status & Co-Education & 410 & 33.25 & 8.543 & & & \\
\cline { 2 - 5 } & Married & 86 & 38.31 & 8.028 & 737 & 4.306 & $0.000^{*}$ \\
\cline { 2 - 5 } & Unmarried & 653 & 34.29 & 8.958 & & & \\
\hline
\end{tabular}

$\mathrm{S}^{* *}=$ Significant at $1 \%$ level. $\mathrm{S}^{*}=$ Significant at $5 \%$ level. 
It is known that the calculated $\rho$ value for the academic achievement is less than 0.05 at 5 percent level of significance. Hence there is significant difference in the academic achievement between male and female D.EI.Ed students. Further it is observed that the female D.EI.Ed students are better than the male D.EI.Ed students in their academic achievement. While comparing the mean scores, female students (mean $=34.92)$ achieve more than male students $($ mean $=32.5)$

The study reveals that, the calculated $\rho$ value for the academic achievement is less that 0.01 and so it is significant at 1percent level. It means that there is significant difference in the academic achievement of D.EI.Ed students due to the nature of institution. Further it is observed that the girls' institution D.EI.Ed students are better than the coeducation institute D.EI.Ed students in their academic achievement. While comparing the mean scores, girls institute $($ mean $=36.64)$ achieve more than co-education institute D.EI.Ed students $($ mean $=33.35)$

It reveals that, the calculated $\rho$ value for the academic achievement is less than 0.01 and so it is significant at $1 \%$ level. It means that there is significant difference in the academic achievement between married and unmarried D.EI.Ed students. Further it is observed that the married D.EI.Ed students are better than the unmarried D.EI.Ed students in their academic achievement. While comparing the mean scores, married D.EI.Ed students (mean = 36.64) achieve more than unmarried D.EI.Ed students (mean $=33.35$ ).

\section{Findings:-}

Findings based on the objectives and followed by date analysis are given as follows: According to the table shows that; there is percent of the elementary teacher trainees have low level, 74 percent have average level and 12.4 percent D.EI.Ed students have high level of emotional intelligence. It is inferred from that; there is 19.8 percent of the D.EI.Ed students have low level, 65.6 percent have moderate level and 14.6 percent have high level of academic achievement. It reveals that; there is no significant difference among the emotional intelligence of D.EI.Ed students in terms of their gender. It is reveals that there is significant difference among the emotional intelligence of D.EI.Ed students in terms of their nature of institution. It reveals that; there is significant difference among the emotional intelligence of D.EI.Ed students in terms of their marital status. It reveals that; there is a significant difference among the academic achievement of D.EI.Ed students in terms of their gender. They showed that; there is significant difference among the academic achievement of D.EI.Ed Students in terms of their nature of institution. They showed that; there is significant difference among the academic achievement of D.EI.Ed students in terms of their marital status.

\section{Educational Implications:-}

Students should be able to recognize their abilities and capacities instead of feeling low develop ability to work and study in adverse emotional condition of life. It can help future teacher to well equip with handling new aims, objectives of education, method of techniques and ready to take the responsibility which is a tactful task. In curriculum impetus should be given for the training of emotional intelligence to increase academic achievement of students.

\section{Conclusion:-}

In the present study, it can be stated that the outcome of all hypothesis is accepted. It is true that there is positive and significant difference between Emotional Intelligence and Academic Achievement. There is a great need to explore the awareness about the Emotional Intelligence. Emotional Intelligent people are more likely to succeed in everything they undertake. Quality emotions and feeling help student gave their best potential in the classroom. The students who are aversive and think negatively cannot concentrate for a long time and have more difficulty in reaching their potential than others. The emotions, feelings and values are vital for a person well being and achievement in life. 


\section{Reference:-}

1. Abi.Sarma N (2000) The relationship between Emotional Intelligence and Academic Achievement in eleventh graders. Research in Education. FED 661.

2. Aggarwal Y P (1990) Statistical Methods, New Delhi: Sterling publisher Pvt. ltd.

3. Brackett M A (2011). Emotional Intelligence: Implications for Personal, Social, Academic and Workplace Success. Soc Personal Psychol Compass. 2011; 5: 88-103. doi:10.1111/j. 1751-9004.2010.00334.x.

4. Kothari C R (1990). Research Methodology Methods and Techniques, Second edition.

5. Lokesh koul (2007) Methodology of Educational Research, Vikas Publishing house Pvt. Ltd.

6. Salovey P \& Mayer J D (1997) What is Emotional Intelligence? In Emotional development and emotional intelligence: Educational implications, NY: Basic Books, 3-34.

7. Sharma P Mangal S \& Nagar P (2016) To Study the Impact of Emotional Intelligence on Academic Achievement of Teacher Trainees. IRA International Journal of Education and Multidisciplinary Studies (ISSN 2455-2526), 4(1). doi:http://dx.doi.org/10.21013/jems.v4.nl.p.6.

8. Smith T M (2009) Integrating multiple intelligences and anagogical principles into a pre-service teacher education programme. Dissertation Abstracts International: Section A, 69 (8), 3113. 